\title{
Petroleum Hydrocarbon Contamination in Terrestrial Ecosystems-Fate and Microbial Responses
}

\author{
Adam Truskewycz ${ }^{1}$, Taylor D. Gundry ${ }^{1}$, Leadin S. Khudur ${ }^{1}$, Adam Kolobaric ${ }^{1}$, \\ Mohamed Taha ${ }^{1,2} \mathbb{D}^{\mathbb{D}}$, Arturo Aburto-Medina ${ }^{1} \mathbb{D}$, Andrew S. Ball ${ }^{1}$ and Esmaeil Shahsavari ${ }^{1, * \mathbb{D}}$ \\ 1 Centre for Environmental Sustainability and Remediation, School of Science, RMIT University, \\ Bundoora, VIC 3083, Australia; adam.truskewycz@rmit.edu.au (A.T.); \\ s3282982@student.rmit.edu.au (T.D.G.); leadin.khudur@rmit.edu.au (L.S.K.); \\ adamkolobaric@gmail.com (A.K.); moohamedtaha@yahoo.com (M.T.); \\ arturoaburto.medina@rmit.edu.au (A.A.-M.); andy.ball@rmit.edu.au (A.S.B.) \\ 2 Department of Biochemistry, Faculty of Agriculture, Benha University, Moshtohor, Toukh, \\ Qaliuobia 13736, Egypt \\ * Correspondence: esmaeil.shahsavari@rmit.edu.au
}

Academic Editor: Łukasz Chrzanowski

Received: 4 July 2019; Accepted: 11 September 2019; Published: 19 September 2019

Abstract: Petroleum hydrocarbons represent the most frequent environmental contaminant. The introduction of petroleum hydrocarbons into a pristine environment immediately changes the nature of that environment, resulting in reduced ecosystem functionality. Natural attenuation represents the single, most important biological process which removes petroleum hydrocarbons from the environment. It is a process where microorganisms present at the site degrade the organic contaminants without the input of external bioremediation enhancers (i.e., electron donors, electron acceptors, other microorganisms or nutrients). So successful is this natural attenuation process that in environmental biotechnology, bioremediation has developed steadily over the past 50 years based on this natural biodegradation process. Bioremediation is recognized as the most environmentally friendly remediation approach for the removal of petroleum hydrocarbons from an environment as it does not require intensive chemical, mechanical, and costly interventions. However, it is under-utilized as a commercial remediation strategy due to incomplete hydrocarbon catabolism and lengthy remediation times when compared with rival technologies. This review aims to describe the fate of petroleum hydrocarbons in the environment and discuss their interactions with abiotic and biotic components of the environment under both aerobic and anaerobic conditions. Furthermore, the mechanisms for dealing with petroleum hydrocarbon contamination in the environment will be examined. When petroleum hydrocarbons contaminate land, they start to interact with its surrounding, including physical (dispersion), physiochemical (evaporation, dissolution, sorption), chemical (photo-oxidation, auto-oxidation), and biological (plant and microbial catabolism of hydrocarbons) interactions. As microorganism (including bacteria and fungi) play an important role in the degradation of petroleum hydrocarbons, investigations into the microbial communities within contaminated soils is essential for any bioremediation project. This review highlights the fate of petroleum hydrocarbons in tertial environments, as well as the contributions of different microbial consortia for optimum petroleum hydrocarbon bioremediation potential. The impact of high-throughput metagenomic sequencing in determining the underlying degradation mechanisms is also discussed. This knowledge will aid the development of more efficient, cost-effective commercial bioremediation technologies.

Keywords: petroleum hydrocarbon (PH); natural attenuation; bioremediation; microbial consortia 


\section{Introduction}

The introduction of petroleum hydrocarbons into a pristine environment immediately changes the nature of that environment. The introduced hydrocarbons kill or inhibit many microbial species, thereby altering the functionality of the microbial community and therefore the ecosystem [1]. Plants exposed to hydrocarbons are also affected by direct toxicity, prevention of access to light, and the inability to acquire nutrients and water due to oil restricting their movement through the soil matrix, all of which significantly impair plant productivity [2]. In the absence of functioning microbial biogeochemical networks and primary producers, the ability for the contaminated habitat to support higher-order life forms is limited.

When petroleum hydrocarbons enter the environment, the process of weathering occurs. Weathering of petroleum hydrocarbons in the environment involves physical (dispersion), physiochemical (evaporation, dissolution, sorption), chemical (photo-oxidation, auto-oxidation), and biological (plant and microbial catabolism of hydrocarbons) influences. The process of biodegradation, the focus of this review, is largely mediated through the natural soil microbial community. Natural attenuation represents the single, most important biodegradative process which removes petroleum hydrocarbons from the environment. It is a process where microorganisms present at the site degrade the organic contaminants without the input of external bioremediation enhancers (i.e., electron donors, electron acceptors, other microorganisms or nutrients) [3].

Microorganisms play a vital role in maintaining an ecologically balanced environment. They are responsible for regulating several processes in the soil ecosystem including recycling of nutrients, the decay of organic materials, and the formation of symbiotic relationships with plants [4]. Petroleum hydrocarbon contamination presents microorganisms with environments which have characteristics not usually experienced in natural conditions. Therefore, understanding the interaction of anthropogenic chemical pollutants within soil and their interactions with microbial communities is very important.

Microorganisms have varying mechanisms for adapting to and catabolizing petroleum hydrocarbons. Although individual microorganisms have mechanisms for hydrocarbon degradation (i.e., the enzyme-catalyzed breakdown of inorganic and organic pollutants) [5], other species may aid in this process by way of symbiotic relationships (i.e., release of glucose to aid in proliferation of hydrocarbon-degrading species or secretion of surfactants to render the oil more bioavailable) [6]. So successful is this natural attenuation process that an environmental biotechnology, bioremediation has developed steadily over the past 50 years based on this natural biodegradation process.

This review aims to describe the fate of petroleum hydrocarbons in the environment and discuss their interactions with abiotic and biotic components under both aerobic and anaerobic conditions. Furthermore, natural mechanisms for dealing with petroleum hydrocarbon contamination will be examined. Through a detailed examination of these processes, greater understanding of the potential of natural attenuation to remove all fractions of petroleum hydrocarbons will result, which can then be used to update sustainable and environmentally friendly bioremediation strategies used in commercial bioremediation.

The development of tailored microbial consortia for specific site conditions and different hydrocarbon classes is proposed. Furthermore, a monitored site remediation approach where differing microbial consortia are introduced at different stages of remediation may promote complete microbial hydrocarbon catabolism. Linking next-generation sequencing with the microbial functional analysis is also identified as an important prerequisite for understanding the capacity of microbial consortia to decontaminate petrogenic hydrocarbons at varying sites.

\section{Oil Composition Changes upon Entering the Environment}

Petrogenic hydrocarbons represent a complex group of pollutants that are usually released into the environment as a mixture consisting of n-alkanes, branched alkanes, cyclo-alkanes, and polyaromatic hydrocarbons (PAHs). These varying hydrocarbon compounds interact differently with their environment, often depending on their molecular weight and properties, with compounds 
varying in size and structure from $\mathrm{C}_{1}$ (methane) to $\mathrm{n}-\mathrm{C}_{40}+$. Petroleum hydrocarbons can be divided into four categories based on their chemical structure - the saturates, the aromatics, the asphaltenes, and the resins [7].

Petroleum hydrocarbons in the environment undergo weathering, which may involve physical (dispersion), physiochemical (evaporation, dissolution, sorption), chemical (photo-oxidation, auto-oxidation), and biological (plant and microbial catabolism of hydrocarbons) influences [8] (Figure 1). Weathering may strongly impact the degradation potential of oil, and the degree and type of weathering will be different from site to site.

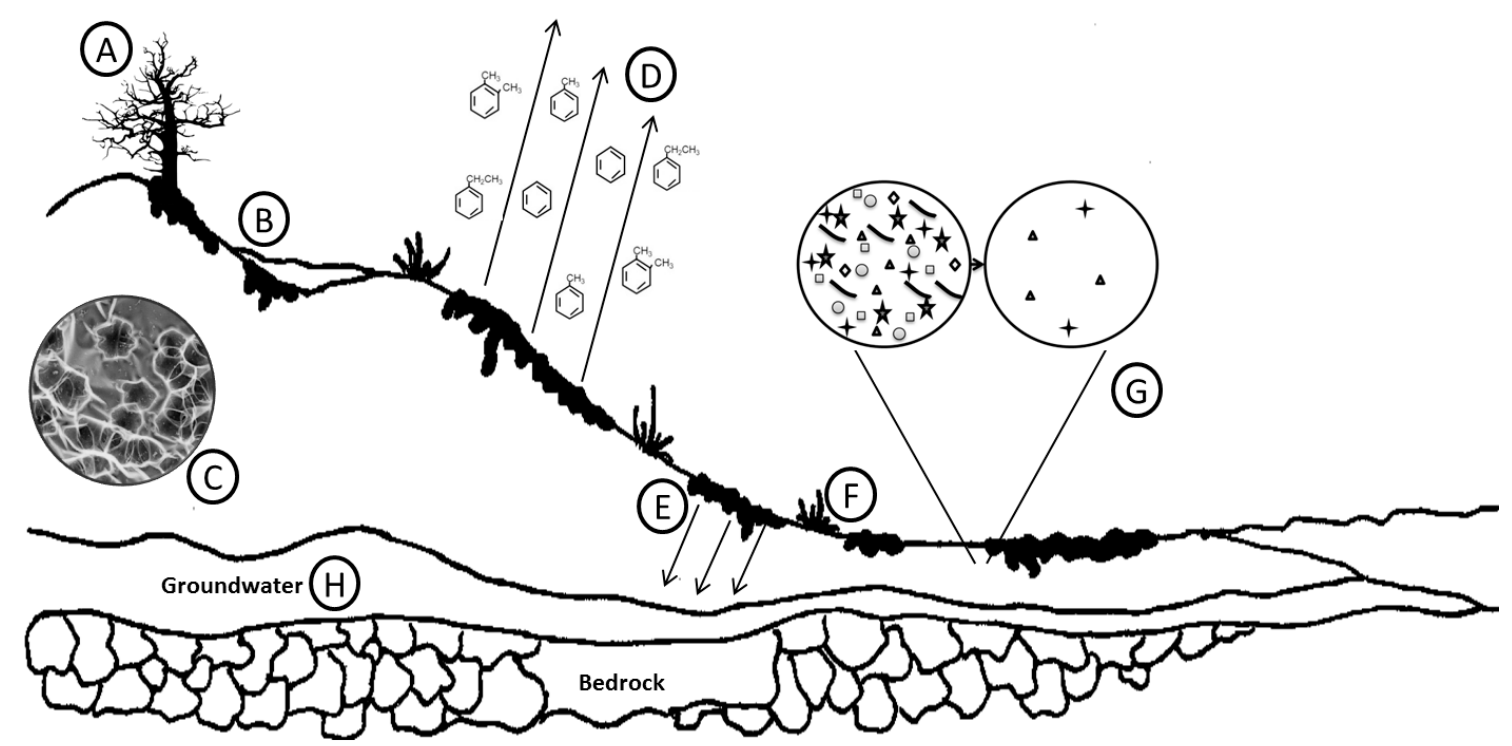

Figure 1. Fate of oil and site characteristic changes following a terrestrial oil spill event: (A) Plant death, (B) anaerobic zones, (C) altered soil structure, (D) volatilization, (E) hydrocarbon percolation, (F) aerobic zones, (G) initial decrease in microbial populations and diversity, (H) hydrocarbon contaminated groundwater.

\subsection{Volatilization}

As the oil spreads over the landscape, the lighter fractions volatilize into the atmosphere. Different petroleum hydrocarbons may behave in different ways. Light crudes and gasoline may evaporate completely in warm conditions if they are not locked up in other environmental interactions, whereas bunker oil may only have volatilization rates of a few percent by weight [9]. Volatilization frees lighter aromatic (i.e., BTEX, and other simple ringed structures) from more complex oil mixtures (Figure 1). Saturated hydrocarbons with 1-5 ring structures are considered to be volatile or semi-volatile. Increasing temperature increases the rate and capacity of volatilization; however, increasing chain length reduces volatility [10]. Volatilization not only occurs on surface-dwelling oil, but it can also occur in the subsurface. Essaid et al. (2011) spent 25 years monitoring and modeling the fate of hydrocarbons from a burst crude oil pipeline in Bemidji, Minnesota, which released 1.7 million liters of oil into the environment. Oil which had percolated through the soil was still volatilizing and was creating a soil vapor plume in the saturated zone [11].

\subsection{Dissolution}

As a hydrocarbons chain length or number of aromatic rings increases, its solubility in water decreases. The dissolved concentration of petroleum hydrocarbons in water is reliant on the composition of the oil. A large quantity of viscous crude oil may have less dissolvable fractions than a smaller quantity of lighter-class oil. Dissolvable fractions at $20^{\circ} \mathrm{C}$ generally possess hydrocarbon chains of below $C_{8}$ [12]; however, the presence of polar nonhydrocarbon substances found within the 
environment can increase the solubility of $\mathrm{C}_{34}{ }^{+} \mathrm{n}$-alkane hydrocarbons in oils [13]. In addition, other light aromatic and polycyclic aromatic compounds (e.g., benzene, toluene, xylene, ethylbenzene (BTEX) and naphthalene) are commonly found within contaminated groundwater [14].

Salinity can have a marked effect on hydrocarbon solubility. In salinities of 350,000 ppm, up to $95 \%$ of all hydrocarbons can be displaced from solution. In addition, both temperature and sorption of hydrocarbons to soils can influence their ability to form a solution in water. Hydrocarbon solubility has shown to logarithmically decrease with the increasing boiling point of a hydrocarbon [13].

\subsection{Sorption and Desorption}

Many fractions of hydrophobic hydrocarbons have an affinity to sorb onto soil particles via several processes. These may include the partitioning of hydrocarbon into soil organic matter, diffusion into nanopores, which are inaccessible to microorganisms, or attachment and formation of strong bonds with sites on soils organic matter [15]. Soil structure and composition are likely to strongly influence sorption and desorption kinetics. Hydrocarbon sorption to soil has shown to increase with increasing organic matter, increasing clay content, and increasing hydrocarbon hydrophobicity. The recalcitrance of aged PAH fractions bound to soil components is increased due to their decreased water solubility and inaccessibility to microorganisms [16].

Desorbing strongly bound hydrocarbons from soil matrices has been achieved through the interaction between oil and bioactive compounds secreted from plants and microorganisms. In addition, plant roots can break apart aggregates and free bound hydrocarbons from nanopores [17]. During bioremediation of contaminated sites, a surfactant is often applied to reduce the viscosity of oil, promoting the release of oil from soil sorption [18]. Desorption of hydrocarbons from soil matrices is also increased with higher sand content, increased temperatures, and increased soil moisture [16].

\section{Toxicity of Hydrocarbons to Microorganisms and Microbial Communities}

Once released into the environment, certain petroleum hydrocarbon fractions exhibit high toxicity to soil biota and have been linked with inducing serious health problems in humans, including cancer [19]. Site contamination with petroleum hydrocarbons reduces the diversity and evenness of a microbial community [20] for a number of reasons including:

- direct toxicity of the chemical compounds,

- the locking away of nutrients and water, preventing microorganisms from obtaining essential building blocks for proliferation,

- difficulty in adjusting to the highly nonpolar conditions, which can cause microbial cells to rupture by dissolving the cytoplasm membrane lipids [20].

Mukherjee et al. (2014) showed that there was a decrease in microbial diversity and evenness in creosote-contaminated soils; however, an increase in total microbial activity was evident. This was likely due to the adaption and/or enrichment of the indigenous soil microflora with hydrocarbon-degrading capacities [20].

Although the vast majority of microorganisms at a given site will be unable to survive a hydrocarbon contamination event, there will be hydrocarbon-tolerant and hydrocarbon-degrading species that will survive and proliferate [1]. The exchange of genetic information, nutrients, or metabolites able to elicit gene activation can occur between microorganisms via a number of mechanisms. Broadly, these include indirect exclusive exchange (e.g., phagosome-mediated transfer), indirect transfer via diffusion of chemicals or direct transfer (e.g., contact-mediated transfer) of cellular content, and/or electron transfer. This transfer of metabolites, nutrients, and other cell-cell interactions may lead to enhanced hydrocarbon-degrading organism fitness or may select for parasites, which will reduce microbial diversity [21].

Khudur et al. (2015) observed changes in bacterial soil communities two weeks after being exposed to diesel at a concentration of $40 \mathrm{~mL} / \mathrm{kg}$ [22]. A significant reduction in microbial diversity and 
evenness was observed. Following hydrocarbon contamination to a site, dynamic ecological balances are altered, and the site becomes dominated with a few select species [23]. However, the number of dominating species rapidly increases within 4 weeks following contamination [24], presumably due to the generation of many degradation intermediates and overall reduced toxicity.

Many changes in the characteristics of a microbial community occur during adaptation of a microbial community following a contamination event. This may include physiological and morphological changes in individual cells, along with changes in the ecological dynamics of the entire community [25].

Physiological characteristics (e.g., growth rates and innate resilience to stressors) can be a driver of adaptation. The diversity of microbial populations may result in favorable genomic variations, some of which may benefit the overall community [24]. Morphological characteristics include any changes in the shape and the size of the microbial cells and may take place to increase their transportation abilities in the soil matrix to reach the contaminants. Concentration and physio-chemical properties of specific contaminants are the major factors for any biological species to form adaptation mechanisms allowing them to use the pollutant as a substrate [26].

The degree of toxicity derived from hydrocarbon contamination on the biota can be influenced by many factors, including:

1. The hydrocarbon fraction itself: In saturated hydrocarbons, the chain length is highly correlated with direct toxicity. Fractions of lower molecular weight structures (C6 to C20) have been shown to be more toxic due to their high bioavailability; however, larger saturated chained hydrocarbons have increased mutagenic potential [5]. The toxicity of unsaturated hydrocarbon structures is not as predictable and may be influenced by reactive functional groups, water and membrane solubility, viscosity, and interactions of these compounds with the membrane and with membrane constituents.

2. The concentration of nutrients: the diversity of the microbial communities in soil with a higher concentration of $\mathrm{N}$ and $\mathrm{P}$ has been shown to increase the abundance and activity of the hydrocarbon-degrading microbial community [22].

3. Co-contamination with other chemicals (i.e., heavy metals): higher toxicity of petroleum hydrocarbon to soil microorganisms was reported with the presence of heavy metals as a co-contaminant when compared with the toxicity of petroleum hydrocarbon as the only contaminant [27]. Khudur et al. (2019) showed that hydrocarbon-contaminated soils were more recalcitrant to microbial bioremediation when co-contaminated with lead $(\mathrm{Pb})$. Lead inhibits many metabolic pathways, such as the enzymatic and respiratory processes of many bacteria, and creates additional stress to hydrocarbon-degrading species [28].

Oil pollution events can have strong, immediate negative effects on the indigenous soil microbial community by reducing the diversity and total biomass [29]. However, the soil microbial community possesses an array of mechanisms of resilience. Bacteria with short life cycles can quickly employ coping strategies to these changes in the environment (i.e., production of secondary metabolites, sporulation, develop mutualistic interactions with other microbial species, etc.) [30]. Microbial biofilms in soil have natural resistance to perturbations as they are able to protect their constituents through slower diffusion rates and the co-metabolism of organic pollutants [31].

\section{Physiochemical Factors Affecting Natural Attenuation of Petrogenic Hydrocarbons}

The potential for natural attenuation of petroleum hydrocarbon-contaminated soil is not only affected by biotic factors, but also by abiotic factors such as salinity, moisture availability, nutrient availability, and soil chemistry. These abiotic factors are influenced by hydrocarbon contamination and significantly affect the capacity for microbial pollution catabolism. 


\subsection{Nutrients and Additives}

For microbial utilization of oil to occur, access to nutrients is required [32]. Nutrients are often locked up by oils and become inaccessible to plants and microorganisms. Nutrients are required for generating the building blocks of new plant and microbial cells, along with supporting the proper functioning of all metabolic and structural processes of cells. In addition, hydrocarbon degradation may utilize certain nutrients as terminal electron acceptors for microbial catabolism pathways (common in anaerobic hydrocarbon degradation) [33].

Changes in nutrient levels also alter ecological relationships and interactions between microbial communities, such as communalism or parasitism relationships. Biostimulation, the application of nutrients has been shown to result in elevated hydrocarbon degradation; however, it has also been shown to select for pathogenic bacterial species which reduce the fitness of other hydrocarbon-degrading species. The addition of complex organic substrates like mature compost can cause desorption of oil from the soil due to its high humic content [34], leading to increased bioavailability of the oily compounds and higher bioremediation rates.

\subsection{Salinity}

High salt concentrations create a selective pressure which makes conditions unfavorable for many microbial species due to changes in osmotic pressure and the locking away of nutrients. "Salting out" occurs when salts reduce the solubility and availability of hydrophobic organic compounds [35]. Salinization of oil fields is a common occurrence [36] which may lead to a decrease in microbial respiration, and consequently a decrease in the rate of bioremediation for a site [37].

Some microbial consortias have been found to be robust and exhibit functional redundancy for the degradation of diesel from saline soils. Riis et al. observed that biodegradation of diesel in soil could be achieved if the salinity was below $15 \%(w / w)$ using consortia from the genera Cellulomonas, Bacillus, Dietzia, and Halomonas. [38]. Kleinsteuber et al. observed that microbial communities from naturally saline soils $(6.4 \% \mathrm{w} / \mathrm{w})$ exhibited functional redundancy for the degradation of diesel, with no significant decrease in activity with increases up to $20 \%(w / w)$ salinity [39]. A common halostress coping mechanism for bacteria is to "salt-in cytoplasm", whereby the bacteria increase the concentration of potassium and chloride ions in their cell [40]. Biostimulation using $\mathrm{K}^{+}$and $\mathrm{Ca}^{2+}$ ions help microorganisms buffer against osmotic stress and can help enhance their hydrocarbonoclastic activity in intertidal sediments [41].

Extreme salinity caused by oil field brine $\left(200 \mathrm{dS}^{1}\right)$ was shown to reduce the microbial oil utilization potential of soil contaminated with motor oil by $44 \%$ in clay loam soils, and $20 \%$ for sandy-clay loam soils [42].

\subsection{Drought/Rainfall/Moisture}

Water is not only necessary for the uptake of nutrients and the secretion of waste products within microbial cells, but is involved in practically all reactions within the cell. Water molecules aid in the stabilization of proteins, DNA, and lipids and in maintaining the structural integrity of microbial cells. Furthermore, water is required extracellularly to transport microbial-derived macromolecules for interactions with the environment. One such example is the transportation of genetic material from one microbial species to another via plasmids $[43,44]$.

The lack of water negatively impacts soil microbial communities by hampering their interactions with each other and the environment, which may lead to a reduction in abundance, diversity, and structure [45]. This phenomenon was observed by [46], where after only 180 days of simulated drought conditions using semiarid agricultural soil from southern Spain, the activity of the soil microbial community substantially decreased, resulting in reduced $\mathrm{C}$ and $\mathrm{N}$ mineralization. These negative effects of drought were abated by the addition of compost to the soil at a rate of $100 \mathrm{t} \mathrm{ha}^{-1}$. 
A combination of phytoremediation and microbial-driven bioremediation may be useful for the remediation of oil contamination under drought conditions. Phillips et al. observed that the microbial communities in the rhizosphere of Altai wild rye plants contained 100 times more endophytic hexadecane degraders than other plants under drought conditions [47]. How microbial communities respond to cycles of extreme desiccation and rewetting may have profound impacts on bioremediation. Small changes in community structure in response to wet/dry cycles may potentially hide large changes in the relative abundance of certain key microbial groups in soil communities [48]. The potential effects of drought on oil bioremediation are not well understood, but extrapolating from general microbial response studies, droughts are likely to reduce oil bioremediation rates [49].

Excess moisture may also impede bioremediation by saturating soil, reducing the capacity of $\mathrm{O}_{2}$ to dissolve into the water. This causes aerobic soils to become anaerobic [50]. Lahel et al. observed $>20 \%$ decrease in remediation efficiency of diesel when moisture was increased from $10 \%$ to $30 \%$ in a series of microcosm experiments [51].

\section{Microbe-Microbe Interactions}

Microorganisms have a tremendous ability to modify their environment to provide ideal conditions for proliferation. A number of microbial relationships enable them to gain a competitive advantage within particular ecological niches and help the microbial community survive in adverse environments. These interactions include; parasitism, predation, competition, amensalism, commensalism, and mutualism [52].

Microbial communities present in natural ecosystems (i.e., bacteria and fungi (from different species)) proliferate together in a synergetic relationship and produce a remarkable cocktail of primary and secondary bioactive molecules (metabolites) including oxidative and hydrolytic enzymes. These natural products are essential for cell proliferation and have been implicated in the mineralization of varying hydrocarbon fractions [53]. Single-strained microbial cultures lack the multitude of hydrocarbon-degrading mechanisms which may be found within a consortium [54,55].

Mixed microbial community interactions have been shown to create conditions favorable for survival. One such example is the commensal relationship between cyanobacteria and other native bacterial species. Cyanobacterial mats were shown to increase the dissolved oxygen concentration in the zone around them through photosynthesis, creating aerobic pockets that were utilized by native bacteria which can degrade hydrocarbons [56]. Table 1 shows several different genes from different microorganisms which are associated with hydrocarbon degradation.

Table 1. Microbial genes implicated in hydrocarbon degradation with their function/pathway and representative host species.

\begin{tabular}{|c|c|c|c|c|}
\hline Genes & Function & $\begin{array}{c}\text { Example Organism of } \\
\text { Origin }\end{array}$ & $\begin{array}{l}\text { Gene Location } \\
\text { (Chromosome or } \\
\text { Plasmid) }\end{array}$ & Reference \\
\hline $\begin{array}{l}\text { Nah genes }(\mathrm{G}, \mathrm{T}, \mathrm{H}, \mathrm{I} \\
\mathrm{N}, \mathrm{L}, \mathrm{O}, \mathrm{M}, \mathrm{K}, \mathrm{J}, \mathrm{Y}, \mathrm{W})\end{array}$ & $\begin{array}{l}\text { Naphthalene catabolic genes (nah } \\
\mathrm{Y} \text { is chemotaxis gene and nah } \mathrm{W} \\
\text { may aid in adapting to extreme } \\
\text { conditions) }\end{array}$ & Pseudomonas putida G7 & $\begin{array}{l}\text { Chromosome } \\
\text { and/or plasmid }\end{array}$ & [57] \\
\hline Ndo genes & Naphthalene dioxygenases & Pseudomonas putida & $\begin{array}{l}\text { Chromosome } \\
\text { and/or plasmid }\end{array}$ & {$[58,59]$} \\
\hline $\begin{array}{l}\text { Dox genes (bphA bphE } \\
\text { bphF bphG) }\end{array}$ & $\begin{array}{l}\text { Dibenzothiophene oxidation } \\
\text { (meta cleavage pathway) }\end{array}$ & Pseudomonas. sp.C18 & Plasmid & [58-60] \\
\hline Pah & $\begin{array}{l}\text { Naphthalene-Phenanthrene } \\
\text { dioxygenase genes }\end{array}$ & $\begin{array}{l}\text { Pseudomonas putida } \\
\text { OUS82, Pseudomonas } \\
\text { aeruginosa Pak1 }\end{array}$ & Plasmid & [58] \\
\hline Nag gene & Naphthalene dioxygenase genes & Ralstonia sp. strain U2 & Plasmid & [61] \\
\hline Phn genes $(\mathrm{C}, \mathrm{I}, \mathrm{H})$ & Phenanthrene degradation genes & $\begin{array}{l}\text { Alcaligenes faecalis } \\
\text { AFK2 strain }\end{array}$ & Plasmid & [62] \\
\hline
\end{tabular}


Table 1. Cont.

\begin{tabular}{|c|c|c|c|c|}
\hline Genes & Function & $\begin{array}{c}\text { Example Organism of } \\
\text { Origin }\end{array}$ & $\begin{array}{l}\text { Gene Location } \\
\text { (Chromosome or } \\
\text { Plasmid) }\end{array}$ & Reference \\
\hline Fln genes (RB, ED1) & Fluorine degradation & $\begin{array}{c}\text { Terrabacter sp. strain } \\
\text { DBF63 }\end{array}$ & Plasmid & [63] \\
\hline $\begin{array}{l}\text { Pht genes (Aa, Ab, B, } \\
\text { Ac, Ad) }\end{array}$ & $\begin{array}{l}\text { Degrading polycyclic aromatic } \\
\text { hydrocarbons (PAHs) to ring } \\
\text { cleavage metabolites (phthalate) }\end{array}$ & $\begin{array}{l}\text { Mycobacterium } \\
\text { vanbaalenii PYR-1 }\end{array}$ & Plasmid & [64] \\
\hline$C A T$ genes $(\mathrm{A}, \mathrm{B}, \mathrm{C}, \mathrm{R})$ & $\begin{array}{l}\text { Catechol catabolic genes, cat } \\
\text { central ortho pathway }\end{array}$ & $\begin{array}{l}\text { Burkholderia strain } \\
\text { LB400 }\end{array}$ & Chromosome & {$[65,66]$} \\
\hline $\begin{array}{l}\text { Pca genes (ligA, fldV, } \\
\text { pmdA, proOa, (ligB, } \\
\text { fldU, pmdB, pmdC, }\end{array}$ & $\begin{array}{l}\text { Catabolism of the phenolic } \\
\text { compounds (protocatechuate) }\end{array}$ & $\begin{array}{l}\text { Agrobacterium } \\
\text { tumefaciens }\end{array}$ & Chromosome & [67] \\
\hline Gdo genes & $\begin{array}{c}\text { Lignin and salicylate degradation } \\
\text { (bacterial and fungal), gentisate } \\
\text { 1,2-dioxygenase, cleavage of the } \\
\text { gentisate aromatic ring }\end{array}$ & $\begin{array}{l}\text { Rhodovulum sp. Strain } \\
\text { NI22, Pseudomonas } \\
\text { alcaligenes NCIMB } 9867 \\
\text { (strain P25X) }\end{array}$ & $\begin{array}{l}\text { Chromosome } \\
\text { and/or plasmid }\end{array}$ & [68-70] \\
\hline $\begin{array}{c}\text { Alk genes }(\mathrm{B}, \mathrm{F}, \mathrm{G}, \mathrm{H}, \mathrm{J} \\
\mathrm{K}, \mathrm{L})\end{array}$ & $\begin{array}{l}\text { Hydroxylation of aliphatic } \\
\text { hydrocarbons }\end{array}$ & Pseudomonas oleovorans & $\begin{array}{l}\text { Chromosome } \\
\text { and/or plasmid }\end{array}$ & {$[71,72]$} \\
\hline Ben genes $(\mathrm{A}, \mathrm{B}, \mathrm{C}, \mathrm{D})$ & Benzoate catabolic & Halomonas organivorans & Chromosome & [71] \\
\hline $\begin{array}{l}C Y P \text { genes }(p b-1, p b-2 \\
\text { and } p b-3, C Y P 153)\end{array}$ & $\begin{array}{c}\text { Fungal and Bacterial } \\
\text { Cytochrome P450 monooxgenase }\end{array}$ & $\begin{array}{c}\text { Basidiomycetes, } \\
\text { Acinetobacter } \\
\text { calcoaceticus EB104 }\end{array}$ & Chromosome & [73] \\
\hline LadA & $\begin{array}{l}\text { Long-chain alkane } \\
\text { mooxygenase-Degradation of } \\
\text { long-chained alkanes }\end{array}$ & $\begin{array}{c}\text { Geobacillus } \\
\text { thermodenitrificans } \\
\text { NG80-2 }\end{array}$ & Plasmid & [71] \\
\hline $\operatorname{Alm}(\mathrm{A})$ & $\begin{array}{c}\text { A flavin-binding } \\
\text { mooxygenase-Degradation of } \\
\text { long-chained alkanes }\end{array}$ & $\begin{array}{c}\text { Acinetobacter sp. DSM } \\
17874\end{array}$ & Chromosome & [71] \\
\hline $\begin{array}{c}\text { Phd genes (E, F, G, H, I, } \\
\text { J, K) }\end{array}$ & $\begin{array}{l}\text { Aromatic hydrocarbon } \\
\text { degradation }\end{array}$ & $\begin{array}{c}\text { Comamonas testosteroni } \\
\text { GZ39 }\end{array}$ & Chromosome & {$[62,74]$} \\
\hline $\begin{array}{c}\text { Nid genes (A, A3, B2, } \\
\text { B3, D, ) }\end{array}$ & Pyrene degradation & $\begin{array}{c}\text { Mycobacterium sp. } \\
\text { PYR-1 }\end{array}$ & Chromosome & [58] \\
\hline TOL genes (xyl) & Toluene degradation & $\begin{array}{l}\text { Pseudomonas putida } \\
\text { mt-2 }\end{array}$ & Plasmid & [75] \\
\hline Alm & N-Alkanes (C32 and beyond) & $\begin{array}{c}\text { Acinetobacter sp. DSM } \\
17874\end{array}$ & Chromosome & [76] \\
\hline Phn genes $(\mathrm{B}, \mathrm{C}, \mathrm{R}, \mathrm{S})$ & PAH degradation & Burkholderia sp. RP007 & Plasmid & [57] \\
\hline Nar genes $(\mathrm{Aa}, \mathrm{Ab}, \mathrm{B})$ & Naphthalene degradation & $\begin{array}{l}\text { Rhodococcus sp. } \\
\text { NCIMB12038 }\end{array}$ & Plasmid & [77] \\
\hline $\operatorname{Nid}(\mathrm{A})$ & $\begin{array}{l}\text { High-molecular-weight pahs } \\
\text { degradation (e.g., pyrene and } \\
\text { Fluoranthene) }\end{array}$ & $\begin{array}{l}\text { Mycobacterium sp. } \\
\quad P Y R-1\end{array}$ & Chromosome & [78] \\
\hline Dbf genes (A1, A2) & $\begin{array}{c}\text { Terminal oxygenase genes of } \\
\text { angular dioxygenase (Fluorine } \\
\text { degradation) }\end{array}$ & $\begin{array}{c}\text { Terrabacter sp. strain } \\
\text { DBF63 }\end{array}$ & Plasmid & [63] \\
\hline Xyl genes $(X, Y, Z, L)$ & M-xylene degradation & Pseudomonas putida mt2 & Plasmid & {$[79,80]$} \\
\hline $\begin{array}{c}\text { Tod genes }(\mathrm{A}, \mathrm{B}, \mathrm{C} 1, \mathrm{C} 2, \\
\mathrm{D}, \mathrm{E}, \mathrm{C} 1 \mathrm{C} 2 \mathrm{BA}, \\
\mathrm{C} 1 \mathrm{C} 2 \mathrm{BAD}, \\
\mathrm{CIC} 2 \mathrm{BADE})\end{array}$ & $\begin{array}{l}\text { Toluene dioxygenase (tod) } \\
\text { metabolism of toluene, benzene, } \\
\text { and ethylbenzene. }\end{array}$ & Pseudomonas putida & $\begin{array}{l}\text { Chromosome } \\
\text { and/or plasmid }\end{array}$ & {$[81,82]$} \\
\hline tom & $\begin{array}{l}\text { Toluene ortho-monooxygenase, } \\
\text { oxidation of the polycyclic } \\
\text { Aromatic hydrocarbons } \\
\text { naphthalene and fluorene }\end{array}$ & $\begin{array}{c}\text { Pseudomonas mendocina } \\
\text { KR1 }\end{array}$ & Plasmid & [83] \\
\hline $\begin{array}{c}\text { Tbu genes }(\mathrm{E}, \mathrm{F}, \mathrm{G}, \mathrm{K}, \mathrm{I}, \\
\mathrm{H}, \mathrm{J})\end{array}$ & BTEX, meta cleavage & $\begin{array}{c}\text { Pseudomonas aeruginosa } \\
\text { PAO1, } R \text {. }\end{array}$ & Chromosome & [84] \\
\hline$X y l(E)$ & $\begin{array}{c}\text { Multicomponent monooxygenase } \\
\text { Enzyme complexes involved in } \\
\text { aerobic benzene, toluene, } \\
\text { ethylbenzene and xylene (BTEX) } \\
\text { degradation } \\
\text { Catechol 2,3-dioxygenase } \\
\text { (ring cleavage reaction in PAH } \\
\text { degradation) }\end{array}$ & $\begin{array}{l}\text { Sphingomonas } \\
\text { yanoikuyae }\end{array}$ & Chromosome & [86] \\
\hline
\end{tabular}


Table 1. Cont.

\begin{tabular}{|c|c|c|c|c|}
\hline Genes & Function & $\begin{array}{c}\text { Example Organism of } \\
\text { Origin }\end{array}$ & $\begin{array}{l}\text { Gene Location } \\
\text { (Chromosome or } \\
\text { Plasmid) }\end{array}$ & Reference \\
\hline $\begin{array}{l}\text { Dmp genes (K, L, M, N, } \\
\mathrm{O}, \mathrm{P}, \mathrm{Q}, \mathrm{B}, \mathrm{C}, \mathrm{D}, \mathrm{E}, \mathrm{H}, \mathrm{F}, \\
\text { G, I) }\end{array}$ & $\begin{array}{l}\text { Involved in the meta cleavage } \\
\text { pathway }\end{array}$ & Pseudomonas sp. CF600 & Plasmid & {$[87,88]$} \\
\hline LiP genes (A, D, LipJ & $\begin{array}{c}\text { Fungal } \\
\text { Lignin peroxidase }\end{array}$ & $\begin{array}{l}\text { Phanerochaete } \\
\text { chrysosporium }\end{array}$ & Chromosome & {$[89,90]$} \\
\hline$M n P$ & $\begin{array}{c}\text { Fungal } \\
\text { Manganese Peroxidase }\end{array}$ & $\begin{array}{l}\text { Phanerochaete } \\
\text { chrysosporium }\end{array}$ & Chromosome & [89] \\
\hline$P O D$ genes & $\begin{array}{l}\text { Fungal Lignin degradation (heme } \\
\text { - peroxidase encoding) }\end{array}$ & $\begin{array}{l}\text { Bjerkandera adusta, } \\
\text { Ganoderma sp. }\end{array}$ & Chromosome & {$[91,92]$} \\
\hline HTP & $\begin{array}{l}\text { Fungal Lignin degradation } \\
\text { heme-thiolate peroxidase (heme - } \\
\text { peroxidase encoding) }\end{array}$ & Rhodonia placenta & Chromosome & [92] \\
\hline$D y P$ & $\begin{array}{l}\text { Fungal Lignin degradation } \\
\text { Dye-decolorizing peroxidase } \\
\text { (heme - peroxidase encoding) }\end{array}$ & $\begin{array}{l}\text { Thanatephorus } \\
\text { cucumeris }\end{array}$ & Chromosome & [92] \\
\hline
\end{tabular}

Mapping the activity and relationships between microorganisms in a complex community over time is a complicated task. However, its importance for generating well-functioning consortia for the specific site and contamination remediation is essential. Deng et al. utilized multiple network approaches to identify the co-occurrence (positive) or mutual exclusion (negative) interactions within microbial communities in groundwater. A positive relationship was more likely to be due to mutualism or commensalism, whereas negative relationships can be attributed to competition, predation, and amensalism [93].

\section{Microbial Hydrocarbon Utilization}

\subsection{Aerobic Hydrocarbon Catabolism}

In aerobic conditions, microbial hydrocarbon degradation is elevated when compared with anaerobic degradation. A driving factor influencing increased respiration in aerobic conditions is that there is no thermodynamically unfavorable requirement to introduce oxygen into the hydrocarbon via hydration [94].

Microbial aerobic catabolism of aliphatic hydrocarbons proceeds when the carbon backbone of the contaminant is cleaved, or functional substitution occurs via the loss of an electron to molecular oxygen [95]. These electron-carrier-dependent reactions are carried out by bacterial mono-oxygenase enzymes, converting the n-alkane hydrocarbon to their respective alcohol [96]. These hydroxylated products then enter peripheral metabolic pathways of the bacterial cell and are further oxidized, breaking apart $\mathrm{C}-\mathrm{C}$ bonds in a step by step manner, resulting in smaller constituents that enter the primary metabolic pathway of the cell via $\beta$-oxidation [97].

Bacterial catabolism of aliphatic compounds has had been widely documented; however aromatic compounds require different microbial metabolic pathways for the attack. With increasing complexity comes increasing recalcitrance to degradation [98]. Low-molecular-weight PAHs (LMW PAHs) are generally more soluble, which increases their bioremediation potential. High-molecular-weight PAHs (HMW PAHs) may be too large to fit into the active site of many enzymes, and alternate degradation pathways may be necessary [58]. Furthermore, their decrease in water solubility and increase in potential carcinogenicity is counterproductive for microbial degradation [77].

Bacterial aerobic degradation of aromatics utilizes oxygen as a final electron acceptor and a substrate for hydroxylation and oxygenolytic ring cleavage reactions [99]. Quintessentially, bacterial aerobic PAH degradation involves the use of oxygenase enzymes (predominantly monooxygenases or dioxygenases). The aromatic ring is hydroxylated via oxygenase enzymes which form a cis-dihydrodiol, which then transforms to a diol intermediate via a dehydrogenase. The ortho-cleavage or meta-cleavage pathways then use oxygenase enzymes to destroy the aromatic ring and produce daughter products (i.e., 
catechols, which later transform to intermediates of the citric acid cycle) [58]. An alternative bacterial PAH-degrading pathway is the P450-mediated pathway, which can also be utilized by nonligninolytic fungi [77]. Several alternative pathways, which all involve the saturated ring cleavage via hydrolysis have been outlined previously [100].

\subsection{Anaerobic Hydrocarbon Catabolism}

The bacterial degradation of hydrocarbons in anaerobic conditions proceeds with metabolic pathways which employ alternative electron acceptors to oxygen $\left(\mathrm{O}_{2}\right)$ (i.e., nitrate, metal ions, and sulphate, to name a few). The type of electron acceptor may vary among environmental site characteristics, different redox zones, and the microorganisms present within. Generally, the first alternative electron acceptor to be used by microorganisms for hydrocarbon catabolism following depletion in atmospheric oxygen is nitrate, as nitrate-reducing bacteria are often facultative anaerobes. Manganese, iron, and sulfate contain redox potentials below that of nitrate and are subsequently employed by their corresponding inorganic ion-reducing bacterial species. Methanogenesis possesses a lower redox potential than that of metal ions and sulfur and is dependent on by-products generated from fermentative and acetogenic bacterial species for supplying electron acceptors (i.e., $\mathrm{H}_{2} / \mathrm{CO}_{2}$, formate/acetate) [101,102].

Five dominant pathways have been identified for anaerobic bacterial hydrocarbon degradation; however, slight variations of these may also transpire. These anaerobic pathways include (1) addition of fumarate to the hydrocarbon chain, (2) hydroxylation of the hydrocarbon chain, (3) carboxylation of aromatics, (4) hydration of alkenes/alkynes, and (5) reverse methanogenesis [102].

\subsubsection{Addition of Fumarate to the Hydrocarbon Chain}

The addition of fumarate to a hydrocarbon chain by anaerobic bacterial species results in a cascade of hydrocarbon chain rearrangements, which ultimately end up being processed by the $\beta$-oxidation pathway, resulting in the formation of alkylsuccinates. These alkylsuccinates can then be degraded by ligation to coenzyme A, carbon-skeleton re-arrangement, and beta-oxidation. Aliphatic and aromatic hydrocarbons can be degraded via this method [103].

Bian et al. (2015) reported the degradation of alkanes via fumarate addition in anaerobic oil reservoirs. This hydrocarbon-degrading mechanism proceeds with alkylsuccinate synthetase facilitating the binding of an n-alkane to the subterminal or terminal (with propane) carbon of fumarate. The resulting products are 2-(1-methylalkyl) succinates (or 2-alkylsuccinates). 2-(1-Methylalkyl) succinate is later rearranged to (2-methylalkyl)-malonyl-CoA, and decarboxylated to a 4-methylalkyl-CoA derivative which undergoes $\beta$-oxidation [104].

A number of nitrifying and sulfate-reducing bacteria (i.e., Thauera aromatic and Desulfobacula toluolica) are able to utilize toluene as a sole carbon source and break it down via the addition of fumarate to the carbon chain. In this process, benzylsuccinate synthase (BSS) facilitates the binding of toluene to the fumarate, forming (R)-benzylsuccinate, which is subsequently metabolized by the $\beta$-oxidation pathway [105].

Safinowski and Meckenstock et al. showed anaerobic degradation of the PAH, 2-methyl-naphthalene by a sulfate-reducing enrichment culture. Within this study, fumarate addition to the methyl group of 2-methylnaphthalene resulted in the formation of 2-napthylmethylsuccinic acid, which was subsequently processed by the $\beta$-oxidation pathway to form 2-naphthoic acid [106].

\subsubsection{Oxygen Independent Hydroxylation of the Hydrocarbon Chain}

For the degradation of numerous ethyl- and propyl-substituted aromatic and heteroaromatic hydrocarbons, oxygen-independent hydroxylation of the hydrocarbon chain is common. Ethylbenzene dehydrogenase $(\mathrm{EBDH})$ catalyzes the hydroxylation of the hydrocarbon chains next to the ring with water (as opposed to $\mathrm{O}_{2}$ in aerobic systems) and converts ring-substituted mono- and bicyclic aromatic compounds to alcohols (e.g., the conversion of ethylbenzene to (S)-1-phenylethanol) [107]. Following 
this, subsequent enzymatic dehydrogenase, carboxylase, and ligase reactions occur before the structure is thiolytically cleaved into benzoyl-CoA and acetyl-CoA [107].

\subsubsection{Carboxylation of Aromatics}

Although the absolute certainty of carboxylation as a hydrocarbon-activating mechanism needs further reinforcement in the literature, identification of aromatic hydrocarbon-derived carboxylic acids with $\mathrm{CO}_{2}$-derived carboxyl groups provides evidence for the activation of hydrocarbons via carboxylation [108].

\subsubsection{Hydration of Alkenes/Alkynes}

Alkene and alkyne hydrocarbons in anaerobic conditions may be degraded via the addition of a water molecule to the unsaturated double or triple bond, converting the parent hydrocarbons to alcohols, ketones, or aldehydes [109]. Rontani et al. utilized bacterial consortia from marine sediments to degrade squalene and suggested an anaerobic degradation pathway where the double bonds were hydrated, resulting in tertiary alcohols and ketones being formed [110].

\subsubsection{Reverse Methanogenesis}

Microbial decomposition of methane is predominantly facilitated via reverse methanogenesis by archaea, although exceptions to this occur. Ettwig et al. showed degradation of methane in anaerobic conditions in the absence of Archaea and reported that the bacterial consortium coupled anaerobic oxidation of methane to denitrification [111].

Anaerobic methane oxidizers degrade methane using a number of different terminal electron acceptors (i.e., nitrate/nitrite, sulfate, iron, and manganese). The exact pathways for reverse methanogenesis have not been fully elucidated as the process is expected to differ between the electron acceptors utilized. The reaction usually proceeds slowly and is dependent on syntrophic/symbiotic interactions between microbial consortia which are difficult or unculturable in laboratory conditions [112].

Anaerobic methanotrophs from the domain archaea are thought to use the reverse reaction of methyl-coenzyme $\mathrm{M}$ reductase (the key enzyme in methanogenesis) for activation of methane. However, the bacterium Methylomirabilis oxyfera has the capacity to convert NO from reduced nitrite to $\mathrm{N}_{2}$ and $\mathrm{O}_{2}$, which makes it possible for methane monooxygenases to attack methane [113].

\subsection{Syntrophy}

Syntrophy is a process whereby the intermediate or end products from one species metabolism are utilized by another to facilitate proliferation (Figure 2) [114]. For microbial anaerobic hydrocarbon degradation, it is common for fermentative, syntrophic, acetogenic, and methanogenic bacteria to form symbiotic relationships [115]. These interactions help to facilitate the progression of otherwise energetically unfavorable reactions (degradation of hydrocarbons via different metabolic pathways) [116].

Within an anoxic hydrocarbon-contaminated site, hydrocarbons, proteins, and polysaccharides may be destroyed by hydrolytic bacteria, forming amino acids, sugars, starches, and fatty acids. These breakdown products can then be utilized by fermentative bacterial species which produce acetate, formate, propionate, butyrate, lactate, carbon dioxide, and hydrogen gas [114] (Figure 2). The resulting conditions are ideal for methanogens to thrive, and they utilize these substrates to generate methane [117]. Reverse methanogens (e.g., methanotrophic bacteria (type II) [117]) can convert methane to carbon dioxide and produce free electrons, which sulfur-reducing bacteria can then utilize to generate hydrogen gas (in sulfate-devoid conditions) [118]. The evolution of hydrogen gas further supports the proliferation of methanogenic species, providing a feedback loop [114]. 


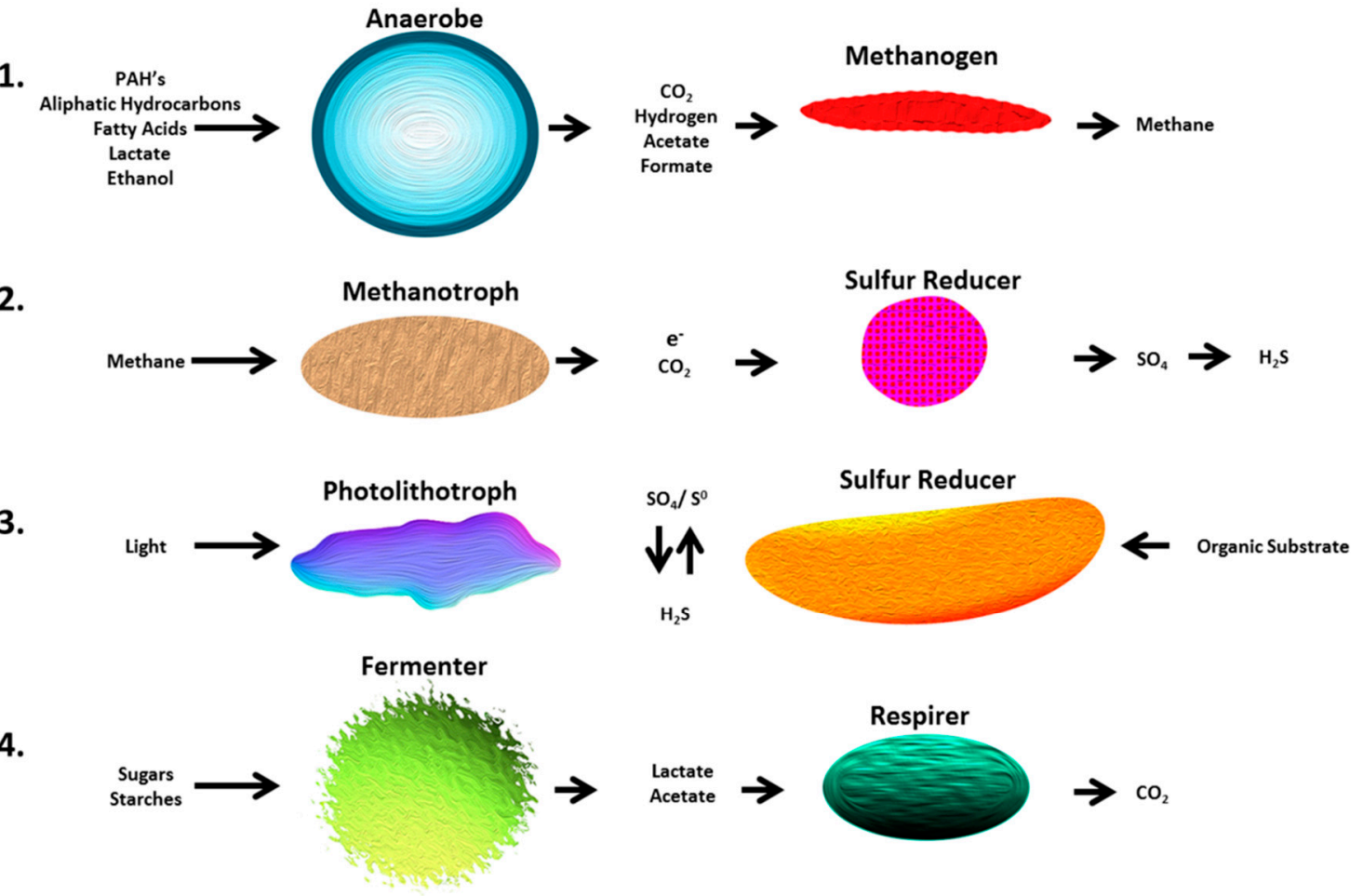

Figure 2. Syntrophic interactions: by-products from one type of microorganism aid in the growth and proliferation of another (adapted from Wintermute \& Silver, 2010, permission has been given by CSHL Press). PAH: polyaromatic hydrocarbon.

The degradation of alkanes in anaerobic conditions has also been reported with the different electron acceptors and methanogenesis. A review by Mbadinga et al. compiled information on the processes and consortia involved in the degradation of these hydrocarbons [119]. Fumarate addition and carboxylation were proposed as the main mechanisms for the initial activation of the alkanes in anaerobic conditions, and the former was confirmed as the exclusive mechanism under sulfate-reducing conditions [120].

Anaerobic degradation of alkylbenzenes coupled to nitrate reduction with symbiotic associations has been observed in an enrichment dominated by Geobacter spp. with annamox bacteria (Plantomycetales) when growing on cyclohexane as the only carbon source [121].

The degradation of alkanes in methanogenic conditions has been reported under two main degradation pathways. Initially, the hydrocarbon is decomposed to acetate and $\mathrm{H}_{2}$ by syntrophic bacteria; following this, methane can be formed by the acetoclastic methanogens such as Methanosatea concilii, while the second pathway includes another group of archaea, the hydrogenotrophic methanogens (Methanospirillum and Methanoculleus) that convert $\mathrm{CO}_{2}$ and $\mathrm{H}_{2}$ to methane.

The anaerobic degradation of BTEX has been studied in several aquifers around the world [122], and some degradation mechanisms have been proposed for benzene [123,124]. Nitrate-, sulfate-, and iron-reducing conditions often result in methanogenesis. Thus, the utilization of hydrocarbons in anoxic conditions has been shown to be carried out by phylogenetically diverse microorganisms. The dominant interactions between these species tend to be syntrophic, with carbon and electron sharing occurring during the degradation pathway.

The taxa involved in the degradation of hydrocarbons has been listed previously [122], and studies dealing with methanogenic hydrocarbon-degrading cultures and their syntrophic processes have been compiled by Gieg and collaborators [125]. Some of the microorganisms involved in the initial attack of hydrocarbons belong to the Pelotomaculum, Clostridium (within the Peptococcaceae) genus, and the Deltaproteobacteria. Some of the Synthropus include the Syntrophoceae and Smithella 
and have been found in multiple contaminated sites [126,127]. The final stages of hydrocarbon degradation in anaerobic conditions are often performed by acetoclastic methanogens such as Methanosaeta concilii or hydrogenotrophic methanogens such as members of the Methanoculleus within the Methanobacteriaceae $[125,128,129]$.

\subsection{Microbial Interactions That Can Indirectly Aid Hydrocarbon Degradation}

Bacteria-bacteria, bacteria-fungi, and bacteria-fungi-plant interactions are ubiquitous in nature and are responsible for a vast array of differing environmental coping mechanisms. Signaling between bacterial species can be both dependent and independent of physical contact. Gram-negative cells tend to secrete low-molecular-weight pheromones (i.e., $\mathrm{N}$-acyl homoserine lactones (AHLs)), which can regulate antibiotic production, cell differentiation, genetic exchange, cell aggregation and biofilm production, protein secretion and so on. [130].

Gram-positive bacteria tend to use small oligopeptides and proteins to transmit information to one another. Oligopeptides usually transfer through the cell membrane and dock to extracellular two-component adaptive-response proteins. These proteins act as receptors and transmit signals for genetic regulation, conjugation, sporulation, virulence, and so on. [131]. A number of microbial species have also adapted both mechanisms as an evolutionary proliferation strategy (i.e., Vibrio harveyi) [132].

Biofilm-producing microbial species are often found within extracellular polymeric substances (EPS). In addition, EPS have been shown to concentrate BTEX pollutants, removing them from soil or water matrices [26]. This barrier can harbor individual species or a number of interacting species and can protect against varying environmental extremes, sheer forces, dehydration, antibiotics, acid and UV damage, predators, and high concentrations of toxic chemicals and pollutants. Biofilms have a strong ability to transfer information via cell-cell contact mechanisms and also through intercellular interactions via chemical signals (i.e., quorum sensing). In some bacterial biofilms (i.e., Alcaligenes sp. strain d2), air-containing cavities are present which facilitate the growth of microcolonies. This phenomenon enables the transportation and removal of biomolecules and oxygen to different members of the community [132].

Oil degradation by microbial interactions can be facilitated by a number of indirect processes. The production of biosurfactants is a common mechanism for bacteria to solubilize viscous oils [133]. This transforms them into a form which is more bioavailable for utilization [26]. Bacteria may also secrete biomolecules that facilitate functional gene expression for hydrocarbon tolerance/degradation reduction in predators through antibiotic production, glucose production to stimulate population growth amongst hydrocarbon degraders, heavy metal chelator production which reduces metals toxicity, extracellular enzymes which may attack recalcitrant hydrocarbons, and so on. [134,135]. In addition, microbial species can secrete molecules that can interact with fungi and plants. One such example is the production of 1-aminocyclopropane-1-carboxylate (ACC) deaminase by a rhizobia bacterium. This molecule alters the plants ethylene production and in turn induces plant tolerance to environmental stresses [136].

\section{Conclusions and Future Directions}

Petroleum hydrocarbons are destructive to ecosystem health, economic health, and human health. Remediation of these sites is therefore necessary to restore functionality, whether that is for environmental preservation or urban development.

Technologies currently used to remove petroleum hydrocarbon-contaminated environments are costly and are often conducted off site, which requires the initial physical removal of contaminated soil. In situ technologies all have their inherent downfalls including high cost (soil flushing), suitability only for specific soil types (soil vapour extraction), inability to remediate all zones of a contaminated site (soil vapour extraction), site may not be used for development following remediation (solidification/stabilization), formation of undesirable by-products (electrokinetic remediation), 
potential for process-induced detrimental effects (chemical oxidation), and inefficient degradation times (bioremediation).

Natural attenuation does not possess the capacity to remediate highly petrochemical contaminated sites at appreciable rates. As a result, alternative technologies such as bioremediation, which is environmentally friendly and cheap compared with conventional treatment approaches, have been developed.

The application of bioremediation techniques has in the past been limited by the knowledge base of environmental science and microbiology. For the site-specific application of bioremediation, the physical and chemical parameters have been the better-understood aspects, thus the basis for models and assessments in the past.

Understanding the complexity of microbial consortium dynamics in terms of degradation of recalcitrant hydrocarbon mixtures has only recently become practicable with the use of affordable/economically viable high-throughput techniques (i.e., next generation sequencing (NGS) and microarray technologies). This area of community interaction analysis for complex environmental systems (i.e., contaminated soil) is still in its infancy; however, without understanding the functional and structural role of microorganisms within whole communities, developing remediation strategies will remain limited.

Author Contributions: A.T. wrote the manuscript. T.D.G., L.S.K., A.K. and M.T. contributed to the collection of literature and summarization. A.A.-M., A.S.B. and E.S. guided throughout the preparation of the paper, proofreading the paper and revised it. All authors fully agreed to its publication.

Funding: This research received no external funding.

Acknowledgments: The authors would like to thank the Members of the Centre for Environment, Sustainability and Remediation (EnSuRe), RMIT University for their assistance and support with this manuscript.

Conflicts of Interest: There is no conflict of interest for this paper.

\section{References}

1. Chikere, C.B.; Okpokwasili, G.C.; Chikere, B.O. Monitoring of microbial hydrocarbon remediation in the soil. 3 Biotech 2011, 1, 117-138. [CrossRef] [PubMed]

2. Nie, M.; Wang, Y.; Yu, J.; Xiao, M.; Jiang, L.; Yang, J.; Fang, C.; Chen, J.; Li, B. Understanding Plant-Microbe Interactions for Phytoremediation of Petroleum-Polluted Soil. PLoS ONE 2011, 6, e17961. [CrossRef] [PubMed]

3. Ellis, E.C. Anthropogenic transformation of the terrestrial biosphere. Philosophical Transactions of the Royal Society A: Mathematical. Phys. Eng. Sci. 2011, 369, 1010-1035. [CrossRef] [PubMed]

4. Van Der Heijden, M.G.A.; Bardgett, R.D.; Van Straalen, N.M. The unseen majority: soil microbes as drivers of plant diversity and productivity in terrestrial ecosystems. Ecol. Lett. 2008, 11, 296-310. [CrossRef] [PubMed]

5. Tang, J.; Lu, X.; Sun, Q.; Zhu, W. Aging effect of petroleum hydrocarbons in soil under different attenuation conditions. Agric. Ecosyst. Environ. 2012, 149, 109-117. [CrossRef]

6. Bak, F.; Bonnichsen, L.; Jørgensen, N.O.G.; Nicolaisen, M.H.; Nybroe, O. The biosurfactant viscosin transiently stimulates n-hexadecane mineralization by a bacterial consortium. Appl. Microbiol. Biotechnol. 2015, 99, 1475-1483. [CrossRef]

7. Colwell, R.R.; Walker, J.D.; Cooney, J.J. Ecological Aspects of Microbial Degradation of Petroleum in the Marine Environment. CRC Crit. Rev. Microbiol. 1977, 5, 423-445. [CrossRef]

8. Boehm, P.D.; Fiest, D.L.; Mackay, D.; Paterson, S. Physical-chemical weathering of petroleum hydrocarbons from the IXTOC I blowout: chemical measurements and a weathering model. Environ. Sci. Technol. 1982, 16, 498-505. [CrossRef]

9. Zhang, Z.; Gai, L.; Hou, Z.; Yang, C.; Ma, C.; Wang, Z.; Sun, B.; He, X.; Tang, H.; Xu, P. Characterization and biotechnological potential of petroleum-degrading bacteria isolated from oil-contaminated soils. Bioresour. Technol. 2010, 101, 8452-8456. [CrossRef] 
10. Van Metre, P.C.; Majewski, M.S.; Mahler, B.J.; Foreman, W.T.; Braun, C.L.; Wilson, J.T.; Burbank, T.L. Volatilization of polycyclic aromatic hydrocarbons from coal-tar-sealed pavement. Chemosphere 2012, 88, 1-7. [CrossRef]

11. Essaid, H.I.; Bekins, B.A.; Herkelrath, W.N.; Delin, G.N. Crude Oil at the Bemidji Site: 25 Years of Monitoring, Modeling, and Understanding. Groundwater 2011, 49, 706-726. [CrossRef] [PubMed]

12. De Hemptinne, J.C.; Delepine, H.; Jose, C.; Jose, J. Aqueous Solubility of Hydrocarbon Mixtures. Revue de l'Institut Français du Pétrole 1998, 53, 409-419. [CrossRef]

13. Lundegard, P.D.; Sweeney, R.E. Total Petroleum Hydrocarbons in Groundwater-Evaluation of Nondissolved and Nonhydrocarbon Fractions. Environ. Forensics 2004, 5, 85-95. [CrossRef]

14. Landmeyer, J.E.; Effinger, T.N. Effect of phytoremediation on concentrations of benzene, toluene, naphthalene, and dissolved oxygen in groundwater at a former manufactured gas plant site, Charleston, South Carolina, USA, 1998-2014. Environ. Earth Sci. 2016, 75, 605. [CrossRef]

15. Regitano, J.B.; Koskinen, W.C.; Sadowsky, M.J. Influence of Soil Aging on Sorption and Bioavailability of Simazine. J. Agric. Food Chem. 2006, 54, 1373-1379. [CrossRef] [PubMed]

16. Providenti, M.A.; Lee, H.; Trevors, J.T. Selected factors limiting the microbial degradation of recalcitrant compounds. J. Ind. Microbiol. Biotechnol. 1993, 12, 379-395. [CrossRef]

17. Khan, S.; Afzal, M.; Iqbal, S.; Khan, Q.M. Plant-bacteria partnerships for the remediation of hydrocarbon contaminated soils. Chemosphere 2013, 90, 1317-1332. [CrossRef] [PubMed]

18. Yadav, A.K.; Manna, S.; Pandiyan, K.; Singh, A.; Kumar, M.; Chakdar, H.; Kashyap, P.L.; Srivastava, A.K. Isolation and characterization of biosurfactant producing Bacillus sp. from diesel fuel-contaminated site. Microbiology 2016, 85, 56-62. [CrossRef]

19. Ball, A.; Truskewycz, A. Polyaromatic hydrocarbon exposure: an ecological impact ambiguity. Environ. Sci. Pollut. Res. 2013, 20, 4311-4326. [CrossRef] [PubMed]

20. Mukherjee, S.; Juottonen, H.; Siivonen, P.; Quesada, C.L.; Tuomi, P.; Pulkkinen, P.; Yrjälä, K. Spatial patterns of microbial diversity and activity in an aged creosote-contaminated site. ISME J. 2014, 8, 2131-2142. [CrossRef]

21. Zengler, K.; Palsson, B.O. A road map for the development of community systems (CoSy) biology. Nat. Rev. Genet. 2012, 10, 366-372. [CrossRef] [PubMed]

22. Khudur, L.S.; Shahsavari, E.; Miranda, A.F.; Morrison, P.D.; Nugegoda, D.; Ball, A.S. Evaluating the efficacy of bioremediating a diesel-contaminated soil using ecotoxicological and bacterial community indices. Environ. Sci. Pollut. Res. 2015, 22, 14809-14819. [CrossRef] [PubMed]

23. van Dorst, J.; Siciliano, S.D.; Winsley, T.; Snape, I.; Ferrari, B.C. Bacterial Targets as Potential Indicators of Diesel Fuel Toxicity in Subantarctic Soils. Appl. Environ. Microbiol. 2014, 80, 4021. [CrossRef] [PubMed]

24. Yan, L.; Sinkko, H.; Penttinen, P.; Lindström, K. Characterization of successional changes in bacterial community composition during bioremediation of used motor oil-contaminated soil in a boreal climate. Sci. Total. Environ. 2016, 542, 817-825. [CrossRef] [PubMed]

25. Semple, K.T.; Doick, K.J.; Wick, L.Y.; Harms, H. Microbial interactions with organic contaminants in soil: Definitions, processes and measurement. Environ. Pollut. 2007, 150, 166-176. [CrossRef]

26. Johnsen, A.R.; Wick, L.Y.; Harms, H. Principles of microbial PAH-degradation in soil. Environ. Pollut. 2005, 133, 71-84. [CrossRef]

27. Thavamani, P.; Malik, S.; Beer, M.; Megharaj, M.; Naidu, R. Microbial activity and diversity in long-term mixed contaminated soils with respect to polyaromatic hydrocarbons and heavy metals. J. Environ. Manag. 2012, 99, 10-17. [CrossRef] [PubMed]

28. Khudur, L.S.; Shahsavari, E.; Webster, G.T.; Nugegoda, D.; Ball, A.S. The impact of lead co-contamination on ecotoxicity and the bacterial community during the bioremediation of total petroleum hydrocarbon-contaminated soils. Environ. Pollut. 2019, 253, 939-948. [CrossRef]

29. Sutton, N.B.; Maphosa, F.; Morillo, J.A.; Al-Soud, W.A.; Langenhoff, A.A.M.; Grotenhuis, T.; Rijnaarts, H.H.M.; Smidt, H. Impact of Long-Term Diesel Contamination on Soil Microbial Community Structure. Appl. Environ. Microbiol. 2013, 79, 619. [CrossRef]

30. Polz, M.F.; Alm, E.J.; Hanage, W.P. Horizontal Gene Transfer and the Evolution of Bacterial and Archaeal Population Structure. Trends Genet. 2013, 29, 170-175. [CrossRef]

31. Burmølle, M.; Ren, D.; Bjarnsholt, T.; Sørensen, S.J. Interactions in multispecies biofilms: do they actually matter? Trends Microbiol. 2014, 22, 84-91. [CrossRef] [PubMed] 
32. Coulon, F.; Pelletier, E.; Gourhant, L.; Delille, D. Effects of nutrient and temperature on degradation of petroleum hydrocarbons in contaminated sub-Antarctic soil. Chemosphere 2005, 58, 1439-1448. [CrossRef]

33. Bento, F.M.; Camargo, F.A.; Okeke, B.C.; Frankenberger, W.T. Comparative bioremediation of soils contaminated with diesel oil by natural attenuation, biostimulation and bioaugmentation. Bioresour. Technol. 2005, 96, 1049-1055. [CrossRef] [PubMed]

34. Plaza, C.; Xing, B.; Fernández, J.M.; Senesi, N.; Polo, A. Binding of polycyclic aromatic hydrocarbons by humic acids formed during composting. Environ. Pollut. 2009, 157, 257-263. [CrossRef] [PubMed]

35. Martins, L.F.; Peixoto, R.S. Biodegradation of petroleum hydrocarbons in hypersaline environments. Braz. J. Microbiol. 2012, 43, 865-872. [CrossRef] [PubMed]

36. Fathepure, B.Z. Recent studies in microbial degradation of petroleum hydrocarbons in hypersaline environments. Front. Microbiol. 2014, 5. [CrossRef]

37. Gao, Y.-C.; Wang, J.-N.; Guo, S.-H.; Hu, Y.-L.; Li, T.-T.; Mao, R.; Zeng, D.-H. Effects of salinization and crude oil contamination on soil bacterial community structure in the Yellow River Delta region. China. Appl. Soil Ecol. 2015, 86, 165-173. [CrossRef]

38. Riis, V.; Kleinsteuber, S.; Babel, W. Influence of high salinities on the degradation of diesel fuel by bacterial consortia. Can. J. Microbiol. 2003, 49, 713-721. [CrossRef]

39. Kleinsteuber, S.; Riis, V.; Fetzer, I.; Harms, H.; Müller, S. Population Dynamics within a Microbial Consortium during Growth on Diesel Fuel in Saline Environmentst. Appl. Environ. Microbiol. 2006, 72, 3531-3542. [CrossRef]

40. Oren, A. Microbial life at high salt concentrations: phylogenetic and metabolic diversity. Saline Syst. 2008, 4, 2. [CrossRef]

41. Al-Mailem, D.; Eliyas, M.; Radwan, S. Bioremediation of oily hypersaline soil and water via potassium and magnesium amendment. Can. J. Microbiol. 2013, 59, 837-844. [CrossRef]

42. Rhykerd, R.L.; Weaver, R.W.; McInnes, K.J. Influence of salinity on bioremediation of oil in soil. Environ. Pollut. 1995, 90, 127-130. [CrossRef]

43. Lorenz, M.G.; Wackernagel, W. Bacterial gene transfer by natural genetic transformation in the environment. Microbiol. Rev. 1994, 58, 563-602.

44. Poté, J.; Ceccherini, M.T.; Van, V.T.; Rosselli, W.; Wildi, W.; Simonet, P.; Vogel, T.M. Fate and transport of antibiotic resistance genes in saturated soil columns. Eur. J. Soil Boil. 2003, 39, 65-71. [CrossRef]

45. Sheik, C.S.; Beasley, W.H.; Elshahed, M.S.; Zhou, X.; Luo, Y.; Krumholz, L.R. Effect of warming and drought on grassland microbial communities. ISME J. 2011, 5, 1692-1700. [CrossRef]

46. Hueso, S.; García, C.; Hernández, T. Severe drought conditions modify the microbial community structure, size and activity in amended and unamended soils. Soil Biol. Biochem. 2012, 50, 167-173. [CrossRef]

47. Phillips, L.A.; Greer, C.W.; Farrell, R.; Germida, J.J. Field-scale assessment of weathered hydrocarbon degradation by mixed and single plant treatments. Appl. Soil Ecol. 2009, 42, 9-17. [CrossRef]

48. Barnard, R.L.; A Osborne, C.; Firestone, M.K. Responses of soil bacterial and fungal communities to extreme desiccation and rewetting. ISME J. 2013, 7, 2229-2241. [CrossRef]

49. Taccari, M.; Milanovic, V.; Comitini, F.; Casucci, C.; Ciani, M. Effects of biostimulation and bioaugmentation on diesel removal and bacterial community. Int. Biodeterior. Biodegrad. 2012, 66, 39-46. [CrossRef]

50. Davis, C.; Cort, T.; Dai, D.; Illangasekare, T.H.; Munakata-Marr, J. Effects of heterogeneity and experimental scale on the biodegradation of diesel. Biodegradation 2003, 14, 373-384. [CrossRef]

51. Lahel, A.; Fanta, A.B.; Sergienko, N.; Shakya, M.; López, M.E.; Behera, S.K.; Rene, E.R.; Park, H.-S. Effect of process parameters on the bioremediation of diesel contaminated soil by mixed microbial consortia. Int. Biodeterior. Biodegrad. 2016, 113, 375-385. [CrossRef]

52. Dheilly, N.M.; Poulin, R.; Thomas, F. Biological warfare: Microorganisms as drivers of host-parasite interactions. Infect. Genet. Evol. 2015, 34, 251-259. [CrossRef]

53. Sabra, W.; Dietz, D.; Tjahjasari, D.; Zeng, A.-P. Biosystems analysis and engineering of microbial consortia for industrial biotechnology. Eng. Life Sci. 2010, 10, 407-421. [CrossRef]

54. Thiengmag, S.; Chuencharoen, S.; Thasana, N.; Whangsuk, W.; Jangiam, W.; Mongkolsuk, S.; Loprasert, S. Bacterial consortium expressing surface displayed, intra- and extracellular lipases and pseudopyronine B for the degradation of oil. Int. J. Environ. Sci. Technol. 2016, 13, 2067-2078. [CrossRef]

55. Varjani, S.J. Microbial degradation of petroleum hydrocarbons. Bioresour. Technol. 2017, 223, $277-286$. [CrossRef] 
56. Abed, R.M.; Köster, J. The direct role of aerobic heterotrophic bacteria associated with cyanobacteria in the degradation of oil compounds. Int. Biodeterior. Biodegrad. 2005, 55, 29-37. [CrossRef]

57. Laurie, A.D.; Lloyd-Jones, G. The phn Genes of Burkholderia sp. Strain RP007 Constitute a Divergent Gene Cluster for Polycyclic Aromatic Hydrocarbon Catabolism. J. Bacteriol. 1999, 181, 531-540.

58. Peng, R.-H.; Xiong, A.-S.; Xue, Y.; Fu, X.-Y.; Gao, F.; Zhao, W.; Tian, Y.-S.; Yao, Q.-H. Microbial biodegradation of polyaromatic hydrocarbons. FEMS Microbiol. Rev. 2008, 32, 927-955. [CrossRef]

59. Kiyohara, H.; Torigoe, S.; Kaida, N.; Asaki, T.; Iida, T.; Hayashi, H.; Takizawa, N. Cloning and characterization of a chromosomal gene cluster, pah, that encodes the upper pathway for phenanthrene and naphthalene utilization by Pseudomonas putida OUS82. J. Bacteriol. 1994, 176, 2439-2443. [CrossRef]

60. Sylvestre, M.; Sirois, M.; Hurtubise, Y.; Bergeron, J.; Ahmad, D.; Shareck, F.; Barriault, D.; Guillemette, I.; Juteau, J.M. Sequencing of Comamonas testosteroni strain B-356-biphenyl/chlorobiphenyl dioxygenase genes: evolutionary relationships among Gram-negative bacterial biphenyl dioxygenases. Gene 1996, 174, 195-202. [CrossRef]

61. Dionisi, H.M.; Chewning, C.S.; Morgan, K.H.; Menn, F.M.; Easter, J.P.; Sayler, G.S. Abundance of dioxygenase genes similar to Ralstonia sp. strain U2 nagAc is correlated with naphthalene concentrations in coal tar-contaminated freshwater sediments. Appl. Environ. Microbiol. 2004, 70, 3988-3995. [CrossRef]

62. Kim, S.-J.; Kweon, O.; Jones, R.C.; Freeman, J.P.; Edmondson, R.D.; Cerniglia, C.E. Complete and integrated pyrene degradation pathway in Mycobacterium vanbaalenii PYR-1 based on systems biology. J. Bacteriol. 2007, 189, 464-472. [CrossRef]

63. Habe, H.; Chung, J.-S.; Kato, H.; Ayabe, Y.; Kasuga, K.; Yoshida, T.; Nojiri, H.; Yamane, H.; Omori, T. Characterization of the Upper Pathway Genes for Fluorene Metabolism in Terrabacter sp. Strain DBF63. J. Bacteriol. 2004, 186, 5938-5944. [CrossRef]

64. Stingley, R.L.; Brezna, B.; Khan, A.A.; Cerniglia, C.E. Novel organization of genes in a phthalate degradation operon of Mycobacterium vanbaalenii PYR-1. Microbiology 2004, 150, 3749-3761. [CrossRef]

65. Antonio, V. The Proceedings from Halophiles 2013, the International Congress on Halophilic Microorganisms; Frontiers Media SA: Lausanne, Switzerland, 2015.

66. Vedler, E. Megaplasmids and the Degradation of Aromatic Compounds by Soil Bacteria. In Microbial Megaplasmids; Edward, S., Ed.; Springer: Berlin/Heidelberg, Germany, 2009; Volume 11, pp. 33-53.

67. Parke, D. Supraoperonic clustering of pca genes for catabolism of the phenolic compound protocatechuate in Agrobacterium tumefaciens. J. Bacteriol. 1995, 177, 3808-3817. [CrossRef]

68. Daval, S.; Lebreton, L.; Gazengel, K.; Boutin, M.; Guillerm-Erckelboudt, A.; Sarniguet, A. The biocontrol bacterium Pseudomonas fluorescens Pf29Arp strain affects the pathogenesis-related gene expression of the take-all fungus Gaeumannomyces graminis var. tritici on wheat roots. Mol. Plant Pathol. 2011, 12, 839-854. [CrossRef]

69. Brown, L.M.; Gunasekera, T.S.; Bowen, L.L.; Ruiz, O.N. Draft Genome Sequence of Rhodovulum sp. Strain NI22, a Naphthalene-Degrading Marine Bacterium. Genome Announc. 2015, 3, e01475-14. [CrossRef]

70. Yeo, C.C.; Wong, M.V.-M.; Feng, Y.; Song, K.P.; Poh, C.L. Molecular characterization of an inducible gentisate 1,2-dioxygenase gene, xlnE, from Pseudomonas alcaligenes NCIMB 9867. Gene 2003, 312, 239-248. [CrossRef]

71. Papke, R.T. Preface to the proceedings of Halophiles 2013. Front. Microbiol. 2015, 6, 341. [CrossRef]

72. Vomberg, A.; Klinner, U. Distribution of alkB genes within n-alkane-degrading bacteria. J. Appl. Microbiol. 2000, 89, 339-348. [CrossRef]

73. Nakamura, R.; Kondo, R.; Shen, M.H.; Ochiai, H.; Hisamatsu, S.; Sonoki, S. Identification of cytochrome P450 monooxygenase genes from the white-rot fungus Phlebia brevispora. AMB Express 2012, 2, 8. [CrossRef]

74. Zylstra, G.J.; Kim, E.; Goyal, A.K. Comparative Molecular Analysis of Genes for Polycyclic Aromatic Hydrocarbon Degradation. In Genetic Engineering: Principles and Methods; Setlow, J.K., Ed.; Springer: Boston, MA, USA, 1997; pp. 257-269.

75. Williams, P.A.; Jones, R.M.; Shaw, L.E. A third transposable element, ISPpu12, from the toluene-xylene catabolic plasmid pWW0 of Pseudomonas putida mt-2. J. Bacteriol. 2002, 184, 6572-6580. [CrossRef]

76. Throne-Holst, M.; Wentzel, A.; Ellingsen, T.E.; Kotlar, H.K.; Zotchev, S.B. Identification of novel genes involved in long-chain n-alkane degradation by Acinetobacter sp. strain DSM 17874. Appl. Environ. Microbiol. 2007, 73, 3327-3332. [CrossRef]

77. Ghosal, D.; Ghosh, S.; Dutta, T.K.; Ahn, Y. Current State of Knowledge in Microbial Degradation of Polycyclic Aromatic Hydrocarbons (PAHs): A Review. Front. Microbiol. 2016, 7, 107. [CrossRef] 
78. Wu, P.; Wang, Y.S.; Sun, F.L.; Wu, M.L.; Peng, Y.L. Bacterial polycyclic aromatic hydrocarbon ring-hydroxylating dioxygenases in the sediments from the Pearl River estuary, China. Appl. Microbiol. Biotechnol. 2014, 98, 875-884. [CrossRef]

79. Kim, E.; Aversano, P.J.; Romine, M.F.; Schneider, R.P.; Zylstra, G.J. Homology between genes for aromatic hydrocarbon degradation in surface and deep-subsurface Sphingomonas strains. Appl. Environ. Microbiol. 1996, 62, 1467-1470.

80. Velazquez, F.; De Lorenzo, V.; Valls, M. The m-xylene biodegradation capacity of Pseudomonas putida mt-2 is submitted to adaptation to abiotic stresses: evidence from expression profiling of xyl genes. Environ. Microbiol. 2006, 8, 591-602. [CrossRef]

81. Zylstra, G.J.; Gibson, D.T. Aromatic Hydrocarbon Degradation: A Molecular Approach. In Genetic Engineering: Principles and Methods; Setlow, J.K., Ed.; Springer: Boston, MA, USA, 1991; pp. 183-203.

82. Busch, A.; Lacal, J.; Silva-Jímenez, H.; Krell, T.; Ramos, J.L. Catabolite Repression of the TodS/TodT Two-Component System and Effector-Dependent Transphosphorylation of TodT as the Basis for Toluene Dioxygenase Catabolic Pathway Control ${ }^{\nabla}$. J. Bacteriol. 2010, 192, 4246-4250. [CrossRef]

83. Tao, Y.; Bentley, W.E.; Wood, T.K. Regiospecific oxidation of naphthalene and fluorene by toluene monooxygenases and engineered toluene 4-monooxygenases ofPseudomonas mendocina KR1. Biotechnol. Bioeng. 2005, 90, 85-94. [CrossRef]

84. Kukor, J.J.; Olsen, R.H. Genetic organization and regulation of a meta cleavage pathway for catechols produced from catabolism of toluene, benzene, phenol, and cresols by Pseudomonas pickettii PKO1. J. Bacteriol. 1991, 173, 4587-4594. [CrossRef]

85. Parales, R.E.; Parales, J.V.; Pelletier, D.A.; Ditty, J.L. Chapter 1 Diversity of Microbial Toluene Degradation Pathways. In Advances in Applied Microbiology; Allen, L., Ed.; Academic Press: Cambridge, MA, USA, 2008; Volume 64, pp. 1-73.

86. Muangchinda, C.; Chavanich, S.; Viyakarn, V.; Watanabe, K.; Imura, S.; Vangnai, A.S.; Pinyakong, O. Abundance and diversity of functional genes involved in the degradation of aromatic hydrocarbons in Antarctic soils and sediments around Syowa Station. Environ. Sci. Pollut. Res. 2015, 22, 4725-4735. [CrossRef] [PubMed]

87. van der Meer, J.R. Evolution of novel metabolic pathways for the degradation of chloroaromatic compounds. Antonie van Leeuwenhoek 1997, 71, 159-178. [CrossRef] [PubMed]

88. Suenaga, H.; Koyama, Y.; Miyakoshi, M.; Miyazaki, R.; Yano, H.; Sota, M.; Ohtsubo, Y.; Tsuda, M.; Miyazaki, K. Novel organization of aromatic degradation pathway genes in a microbial community as revealed by metagenomic analysis. ISME J. 2009, 3, 1335-1348. [CrossRef] [PubMed]

89. Stuardo, M.; Vásquez, M.; Vicuña, R.; González, B. Molecular approach for analysis of model fungal genes encoding ligninolytic peroxidases in wood-decaying soil systems. Lett. Appl. Microbiol. 2004, 38, 43-49. [CrossRef] [PubMed]

90. Dashtban, M.; Schraft, H.; Syed, T.A.; Qin, W. Fungal biodegradation and enzymatic modification of lignin. Int. J. Biochem. Mol. Boil. 2010, 1, 36-50.

91. Jansa, J.; Treseder, K.K. Chapter 19: Introduction: Mycorrhizas and the carbon cycle. In Mycorrhizal Mediation of Soil: Fertility, Structure, and Carbon Storage; Johnson, N.C., Gehring, C., Jansa, J., Eds.; Elsevier: Amsterdam, The Netherlands, 2016; Volume 1, pp. 343-351.

92. Ruiz-Dueñas, F.J.; Lundell, T.; Floudas, D.; Nagy, L.G.; Barrasa, J.M.; Hibbett, D.S.; Martinez, A.T.; Mgbeahuruike, A.C.; Kovalchuk, A.; Asiegbu, F.O. Lignin-degrading peroxidases in Polyporales: an evolutionary survey based on 10 sequenced genomes. Mycologia 2013, 105, 1428-1444. [CrossRef] [PubMed]

93. Deng, Y.; Zhang, P.; Qin, Y.; Tu, Q.C.; Yang, Y.F.; He, Z.; Schadt, C.W.; Zhou, J.Z. Network succession reveals the importance of competition in response to emulsified vegetable oil amendment for uranium bioremediation. Env. Microbiol. 2016, 18, 205-218. [CrossRef] [PubMed]

94. Cao, B.; Nagarajan, K.; Loh, K.-C. Biodegradation of aromatic compounds: current status and opportunities for biomolecular approaches. Appl. Microbiol. Biotechnol. 2009, 85, 207-228. [CrossRef] [PubMed]

95. Das, N.; Chandran, P. Microbial degradation of petroleum hydrocarbon contaminants: An overview. Biotechnol. Res. Int. 2011, 2011, 941810. [CrossRef] [PubMed]

96. Rojo, F. Degradation of alkanes by bacteria. Environ. Microbiol. 2009, 11, 2477-2490. [CrossRef] 
97. Moreno, R.; Rojo, F. Enzymes for Aerobic Degradation of Alkanes in Bacteria. In Aerobic Utilization of Hydrocarbons, Oils, and Lipids; Rojo, F., Ed.; Springer Science and Business Media LLC: Berlin, Germany, 2017; pp. 1-25.

98. Seo, J.-S.; Keum, Y.-S.; Li, Q.X. Bacterial Degradation of Aromatic Compounds. Int. J. Environ. Res. Public Health 2009, 6, 278-309. [CrossRef] [PubMed]

99. Carmona, M.; Zamarro, M.T.; Blázquez, B.; Durante-Rodríguez, G.; Juárez, J.F.; Valderrama, J.A.; Barragán, M.J.L.; García, J.L.; Diaz, E. Anaerobic Catabolism of Aromatic Compounds: a Genetic and Genomic View. Microbiol. Mol. Biol. Rev. 2009, 73, 71-133. [CrossRef] [PubMed]

100. Fuchs, G.; Boll, M.; Heider, J. Microbial degradation of aromatic compounds - from one strategy to four. Nat. Rev. Genet. 2011, 9, 803-816. [CrossRef] [PubMed]

101. Ghattas, A.-K.; Fischer, F.; Wick, A.; Ternes, T.A. Anaerobic biodegradation of (emerging) organic contaminants in the aquatic environment. Water Res. 2017, 116, 268-295. [CrossRef] [PubMed]

102. Abbasian, F.; Lockington, R.; Megharaj, M.A.; Naidu, R. Review on the Genetics of Aliphatic and Aromatic Hydrocarbon Degradation. Appl. Biochem. Biotechnol. 2016, 178, 224-250. [CrossRef] [PubMed]

103. Musat, F. The anaerobic degradation of gaseous, nonmethane alkanes - From in situ processes to microorganisms. Comput. Struct. Biotechnol. J. 2015, 13, 222-228. [CrossRef] [PubMed]

104. Bian, X.-Y.; Mbadinga, S.M.; Liu, Y.-F.; Yang, S.-Z.; Liu, J.-F.; Ye, R.-Q.; Gu, J.-D.; Mu, B.-Z. Insights into the Anaerobic Biodegradation Pathway of n-Alkanes in Oil Reservoirs by Detection of Signature Metabolites. Sci. Rep. 2015, 5, 9801. [CrossRef] [PubMed]

105. Qiao, C.; Marsh, E.N.G. Mechanism of Benzylsuccinate Synthase: Stereochemistry of Toluene Addition to Fumarate and Maleate. J. Am. Chem. Soc. 2005, 127, 8608-8609. [CrossRef] [PubMed]

106. Safinowski, M.; Meckenstock, R.U. Methylation is the initial reaction in anaerobic naphthalene degradation by a sulfate-reducing enrichment culture. Environ. Microbiol. 2006, 8, 347-352. [CrossRef]

107. Rabus, R.; Boll, M.; Heider, J.; Meckenstock, R.U.; Buckel, W.; Einsle, O.; Ermler, U.; Golding, B.T.; Gunsalus, R.P.; Kroneck, P.M.; et al. Anaerobic Microbial Degradation of Hydrocarbons: From Enzymatic Reactions to the Environment. J. Mol. Microbiol. Biotechnol. 2016, 26, 5-28. [CrossRef]

108. Widdel, F.; Musat, F. Diversity and Common Principles in Enzymatic Activation of Hydrocarbons. In Handbook of Hydrocarbon and Lipid Microbiology; Kenneth, N.T., Ed.; Springer Science and Business Media LLC: Berlin, Germany, 2010; pp. 981-1009.

109. Grossi, V.; Cravo-Laureau, C.; Rontani, J.-F.; Cros, M.; Hirschler-Réa, A. Anaerobic oxidation of n-alkenes by sulphate-reducing bacteria from the genus Desulfatiferula: n-Ketones as potential metabolites. Res. Microbiol. 2011, 162, 915-922. [CrossRef] [PubMed]

110. Rontani, J.-F.; Mouzdahir, A.; Michotey, V.; Bonin, P. Aerobic and anaerobic metabolism of squalene by a denitrifying bacterium isolated from marine sediment. Arch. Microbiol. 2002, 178, 279-287. [CrossRef] [PubMed]

111. Ettwig, K.F.; Shima, S.; Kahnt, J.; Medema, M.H.; Camp, H.J.M.O.D.; Jetten, M.S.M.; Strous, M.; Van De Pas-Schoonen, K.T.; Van De Pas-Schoonen, K.T. Denitrifying bacteria anaerobically oxidize methane in the absence ofArchaea. Environ. Microbiol. 2008, 10, 3164-3173. [CrossRef] [PubMed]

112. Cui, M.; Ma, A.; Qi, H.; Zhuang, X.; Zhuang, G. Anaerobic oxidation of methane: An "active" microbial process. MicrobiologyOpen 2015, 4, 1-11. [CrossRef] [PubMed]

113. Fan, L.; Reynolds, D.; Liu, M.; Stark, M.; Kjelleberg, S.; Webster, N.S.; Thomas, T. Functional equivalence and evolutionary convergence in complex communities of microbial sponge symbionts. Proc. Natl. Acad. Sci. USA 2012, 109, E1878-E1887. [CrossRef] [PubMed]

114. Wintermute, E.H.; Silver, P.A. Dynamics in the mixed microbial concourse. Genes Dev. 2010, 24, $2603-2614$. [CrossRef] [PubMed]

115. Seth, E.C.; Taga, M.E. Nutrient cross-feeding in the microbial world. Front. Microbiol. 2014, 5. [CrossRef] [PubMed]

116. Shah, F.A.; Mahmood, Q.; Shah, M.M.; Pervez, A.; Asad, S.A. Microbial Ecology of Anaerobic Digesters: The Key Players of Anaerobiosis. Sci. World J. 2014, 2014, 1-21.

117. Hanson, R.S.; Hanson, T.E. Methanotrophic bacteria. Microbiol. Rev. 1996, 60, 439-471.

118. Plugge, C.M.; Zhang, W.; Scholten, J.C.M.; Stams, A.J.M. Metabolic Flexibility of Sulfate-Reducing Bacteria. Front. Microbiol. 2011, 2, 81. [CrossRef] 
119. Mbadinga, S.M.; Wang, L.-Y.; Zhou, L.; Liu, J.-F.; Gu, J.-D.; Mu, B.-Z. Microbial communities involved in anaerobic degradation of alkanes. Int. Biodeterior. Biodegrad. 2011, 65, 1-13. [CrossRef]

120. Aitken, C.; Jones, D.; Maguire, M.; Gray, N.; Sherry, A.; Bowler, B.; Ditchfield, A.; Larter, S.; Head, I.; Larter, S. Evidence that crude oil alkane activation proceeds by different mechanisms under sulfate-reducing and methanogenic conditions. Geochim. Et Cosmochim. Acta 2013, 109, 162-174. [CrossRef]

121. Musat, F.; Wilkes, H.; Behrends, A.; Woebken, D.; Widdel, F. Microbial nitrate-dependent cyclohexane degradation coupled with anaerobic ammonium oxidation. ISME J. 2010, 4, 1290-1301. [CrossRef] [PubMed]

122. Kleinsteuber, S.; Schleinitz, K.M.; Vogt, C. Key players and team play: anaerobic microbial communities in hydrocarbon-contaminated aquifers. Appl. Microbiol. Biotechnol. 2012, 94, 851-873. [CrossRef] [PubMed]

123. Ulrich, A.C.; Beller, H.R.; Edwards, E.A. Metabolites detected during biodegradation of 13C6-benzene in nitrate-reducing and methanogenic enrichment cultures. Environ. Sci. Technol. 2005, 39, 6681-6691. [CrossRef] [PubMed]

124. Coates, J.D.; Chakraborty, R.; McInerney, M.J. Anaerobic benzene biodegradation-a new era. Res. Microbiol. 2002, 153, 621-628. [CrossRef]

125. Gieg, L.M.; Fowler, S.J.; Berdugo-Clavijo, C. Syntrophic biodegradation of hydrocarbon contaminants. Curr. Opin. Biotechnol. 2014, 27, 21-29. [CrossRef]

126. Gray, N.D.; Sherry, A.; Grant, R.J.; Rowan, A.K.; Hubert, C.R.J.; Callbeck, C.M.; Aitken, C.M.; Jones, D.M.; Adams, J.J.; Larter, S.R.; et al. The quantitative significance of Syntrophaceae and syntrophic partnerships in methanogenic degradation of crude oil alkanes. Environ. Microbiol. 2011, 13, 2957-2975. [CrossRef]

127. Gray, N.D.; Sherry, A.; Hubert, C.; Dolfing, J.; Head, I.M. Chapter 5 - Methanogenic Degradation of Petroleum Hydrocarbons in Subsurface Environments: Remediation, Heavy Oil Formation, and Energy Recovery. In Advances in Applied Microbiology; Laskin, A.I., Sariaslani, S., Gadd, G.M., Eds.; Academic Press: Cambridge, MA, USA, 2010; Volume 72, pp. 137-161.

128. Aburto, A.; Fahy, A.; Coulon, F.; Lethbridge, G.; Timmis, K.N.; Ball, A.S.; McGenity, T.J. Mixed aerobic and anaerobic microbial communities in benzene-contaminated groundwater. J. Appl. Microbiol. 2009, 106, 317-328. [CrossRef]

129. Aburto-Medina, A.; Ball, A.S. Microorganisms involved in anaerobic benzene degradation. Ann. Microbiol. 2015, 65, 1201-1213. [CrossRef]

130. Lade, H.; Paul, D.; Kweon, J.H. N-Acyl Homoserine Lactone-Mediated Quorum Sensing with Special Reference to Use of Quorum Quenching Bacteria in Membrane Biofouling Control. BioMed Res. Int. 2014, 2014, 1-25. [CrossRef] [PubMed]

131. Miller, M.B.; Bassler, B.L. Quorum Sensing in Bacteria. Annu. Rev. Microbiol. 2001, 55, 165-199. [CrossRef] [PubMed]

132. Voloshin, S.A.; Kaprelyants, A.S. Cell-cell interactions in bacterial populations. Biochemistry (Moscow) 2004, 69, 1268-1275. [CrossRef] [PubMed]

133. Antoniou, E.; Fodelianakis, S.; Korkakaki, E.; Kalogerakis, N. Biosurfactant production from marine hydrocarbon-degrading consortia and pure bacterial strains using crude oil as carbon source. Front. Microbiol. 2015, 6, 274. [CrossRef] [PubMed]

134. El Amrani, A.; Dumas, A.-S.; Wick, L.Y.; Yergeau, E.; Berthomé, R. “Omics” Insights into PAH Degradation toward Improved Green Remediation Biotechnologies. Environ. Sci. Technol. 2015, 49, 11281-11291. [CrossRef] [PubMed]

135. Galán, J.E.; Lara-Tejero, M.; Marlovits, T.C.; Wagner, S. Bacterial Type III Secretion Systems: Specialized Nanomachines for Protein Delivery into Target Cells. Annu. Rev. Microbiol. 2014, 68, 415-438. [CrossRef] [PubMed]

136. Bonfante, P.; Anca, I.-A. Plants, Mycorrhizal Fungi, and Bacteria: A Network of Interactions. Annu. Rev. Microbiol. 2009, 63, 363-383. [CrossRef]

(C) 2019 by the authors. Licensee MDPI, Basel, Switzerland. This article is an open access article distributed under the terms and conditions of the Creative Commons Attribution (CC BY) license (http://creativecommons.org/licenses/by/4.0/). 